\title{
Biodegradation of Terephthalic Acid by Isolated Active Sludge Microorganisms and Monitoring of Bacteria in a Continuous Stirred Tank Reactor
}

Didem Aksu ${ }^{1}$

https://orcid.org/0000-0002-7184-4011

\section{Caner Vural ${ }^{2}$}

https://orcid.org/0000-0003-1400-6377

Burçin Karabey ${ }^{3}$

https://orcid.org/0000-0003-4834-6740

\section{Guven Ozdemir ${ }^{2 *}$}

https://orcid.org/0000-0002-7577-4233

${ }^{1}$ Ege University Application and Research Center for Testing and Analysis, İzmir, Turkey; ${ }^{2}$ Ege University, Faculty of Science, Dept. of Biology, Basic and Industrial Microbiology Section, Bornova, İzmir, Turkey; ${ }^{3}$ Ordu University, Faculty of Arts and Science, Department of Molecular Biology and Genetics, Ordu, Turkey.

Editor-in-Chief: Paulo Vitor Farago

Associate Editor: Ana Cláudia Barana

Received: 2020.01.29; Accepted: 2020.08.09.

${ }^{*}$ Corresponding author: e-mail: guven.ozdemir@ege.edu.tr; Tel: +90 2323111519 (G.O.).

\section{HIGHLIGHTS}

- Terephthalic acid one of the phthalates has been known endocrine disrupting chemical and degraded by bacterial strains.

- Four bacterial isolates identified as Arthrobacter sp., Chryseobacterium sp. Burkholderia sp. and Pseudomonas sp are able to degrade $100 \mathrm{mgL}^{-1}$ concentration terephthalic acid.

- In order to monitory bacteria in CSTR reactor, Real-time PCR was used.

Abstract: Terephthalic acid is extensively used as an important raw material in polyester fibers, as well as the production of polyethylene terephthalate bottles and textile industries. Especially, in the petrochemical industry, toxic chemicals are released to the atmosphere during the production of polyethylene terephthalate, unless the wastewater treatment is carried out. It's a well-known fact that chemicals have serious side effects on human health, so manufacturing companies should not dispose of such harmful chemicals without treatment. Biodegradation is an effective option for eco-friendly degradation of hydrocarbons. Hydrocarbondegrading bacteria are everywhere in environment and can utilize these chemicals as sources of carbon and energy. In the present study, aerobic bacterial strains T1, T4, T5, and TK were isolated from activated sludge and crude oil deposits of a petrochemical company in Turkey. The strains were identified to be Pseudomonas sp., Chryseobacterium sp., Burkholderia sp., and Arthrobacter sp. according to morphological, physiological and biochemical characteristics. The strains were able to degrade about $100 \%$ of $100 \mathrm{mg} / \mathrm{L}$ terephthalic acid within, respectively, $8,67,52,24$ hour as sole carbon and energy source. Therefore, these isolates can be 
effectively used for degradation of terephthalic acid contaminated sites. In addition to this, a Continuous Stirred Tank Reactor (CSTR) was used to test the biodegradation capabilities of the isolates in the activated sludge system. Throughout the biodegradation, bacterial existence and numbers were monitored using designed primer-probe sets in real-time polymerase chain reaction (PCR).

Keywords: biodegradation; Terephthalic acid; HPLC (High-Performance Liquid Chromatography); real-time PCR; CSTR (Continuous Stirred Tank Reactor).

\section{INTRODUCTION}

Terephthalic acid (TA) is one isomer of the three phthalic acids [1]. Phthalic acid isomers are used for manufacturing plastic bottles, fibers, dye, cellulose film coating, adhesives, polyvinyl chloride (PVC) resins and they are also used in cosmetics, insecticides, and propellants all over the world [2,3]. However, TA is the raw material of polyester fibers and polyethylene terephthalate (PET). PET is produced from TA and ethylene glycol. These chemicals are derived from a petroleum compound and several million tons of them are produced annually [4]. Phthalates are on the list of priority pollutants according to the USA Environmental Protection Agency $[5,6]$. Toxic chemicals are released to the atmosphere during the production of terephthalic acid. It's a well-known fact that chemicals have serious side effects on human health, so manufacturing companies should not dispose of such harmful chemicals without wastewater treatment. These are endocrine-disrupting chemicals and have been found to be harmful to human and animal health and have hepatotoxic, teratogenic and carcinogenic properties $[7,8,9]$.

Recently, biological treatment technology has developed rapidly. Several studies have indicated that aerobic or anaerobic microorganisms play the major roles in the phthalates degradation in the environment $[10,11,12,13,14,15]$. Mechanical and chemical methods of removing hydrocarbons from contaminated sites are highly expensive. For this reason, biodegradation (biological method) is the preferred method in most wastewater treatment systems. Another advantage of biodegradation is converting the toxic material to less hazardous or nonhazardous compounds by microorganisms [16,17,18]. The biological treatment (biodegradation), particularly by the activated sludge process was generally used for degradation of chemicals like TA from petrochemical wastewater [19]. Bacterial cultures have recently been added to wastewater treatment as commercial products [20].

Many studies have reported that biodegradation of TA occurs in aerobic or anaerobic conditions. Arthrobacter sp. 0574, Pseudomonas sp., Bacillus sp., Comamonas testosterone and Rhodococcus biphenylivorans have studied on biodegradation of TA and effectiveness results have achieved $[10,21,22,23,24,25,26,27]$. Recent studies suggest that applications of molecular techniques using real-time PCR to environmental samples have proven to the practicable. Real-time PCR technique using a fluorogenic probe and specific primers allows for rapid detection and numbers of various environmental microorganisms $[28,29,30]$.

The present research study was aimed to isolate TA degrading and with using bacterial isolates which have degradation abilities in Continuous Stirred Tank Reactor (CSTR). Also, Chryseobacterium sp. and Burkholderia sp. which are in CSTR were quantified using real-time PCR.

\section{MATERIAL AND METHODS}

\section{Chemical}

TA was purchased from Sigma Aldrich (185361) and used as hydrocarbon source. TA was dissolved in dimethyl sulfoxide (DMSO) as a stock solution which was $2000 \mathrm{mgL}^{-1}$. The stock solution was stored at $4{ }^{\circ} \mathrm{C}$ for further use.

\section{Isolation of TA degrading strains from petrochemical wastewater}

Activated sludge and wastewater samples were collected from aeration pool of wastewater treatment plants and crude oil deposits of a petrochemical company in Aliağa-Izmir, Turkey in different seasons and examined for isolation of TA degrading bacteria. The samples were stored at $4{ }^{\circ} \mathrm{C}$ until inoculation time. Bacterial cultures were selected in flasks filled with $50 \mathrm{~mL}$ Bushnell Haas (BH) medium (Sigma-AldrichB5051) which was autoclaved at $121^{\circ} \mathrm{C}$ for $15 \mathrm{~min}$ [31]. As a sole carbon source, $100 \mathrm{mgL}^{-1} \mathrm{TA}$ was added to each flask. Then, approximately $2.5 \mathrm{~g}$ of activated sludge and $2.5 \mathrm{~mL}$ wastewater samples were put in the $50 \mathrm{~mL}$ flask and adjusted to $\mathrm{pH} 7.5-8$. The flask was incubated at $30^{\circ} \mathrm{C}$ on an incubator shaker (New 
Brunswick Scientific Innova 4340) at $150 \mathrm{rpm}$ for 7 days [24]. Then, $2.5 \mathrm{~mL}$ of the enriched culture was transferred to a new flask which contains fresh $\mathrm{BH}$ medium and incubated under the same conditions. This operation has been repeated four times to obtain enriched TA degrading bacteria.

At the end of the bacterial screening process, bacterial strains in the consortium were isolated by spreading the serially diluted ten-fold consortium onto $\mathrm{BH}$ agar plates added with $100 \mathrm{mgL}^{-1} \mathrm{TA}$. Then, morphologically different bacterial colonies were selected and separately streaked on Plate Count Agar (PCA, Merck 105463) to obtain a pure culture of the bacterial isolates.

\section{Identification of microorganisms}

Purified strains were then identified by biochemical tests such as Gram staining, potassium hydroxide test $(\mathrm{KOH})$, catalase and oxidase test. For the identification of isolated bacterial cultures, genomic DNA was extracted with Zymo-ZR Fungal/Bacterial DNA Kit. It was used in accordance with the manufacturer's instructions. The 16S rDNA genes were amplified using the universal primers 27F (5'AGAGTTTGATCMTGGCTCAG-3') and 1492R (5'-GGTTACCTTGTTACGACTT-3) [24,32]. Polymerase chain reaction (PCR) is an amplification technique that includes three different steps (denaturation, annealing, and extension). Initial denaturation step: 1 cycle of $95{ }^{\circ} \mathrm{C}$ for $120 \mathrm{~s}$, denaturation step: $95{ }^{\circ} \mathrm{C}$ for $20 \mathrm{~s}$, annealing step: at $56 \stackrel{\circ}{\circ} \mathrm{C}$ for $40 \mathrm{~s}$, extension step: 30 cycles of $72 \stackrel{\circ}{\circ} \mathrm{C}$ for $90 \mathrm{~s}$; and final extension step: $72{ }^{\circ} \mathrm{C}$ for $5 \mathrm{~min}$.

\section{HPLC analysis}

High-performance liquid chromatography (HPLC) analysis was performed to screen the TA degradation ability of the isolates The bacterial strains were subjected to shake flask incubation $\left(30^{\circ} \mathrm{C}, 150 \mathrm{rpm}\right)$ with 100 $\mathrm{mgL}^{-1} \mathrm{TA}$ in $\mathrm{BH}$ medium in $250 \mathrm{~mL}$ Erlenmeyer flasks. Inoculums were prepared in nutrient broth $(0.5$ McFarland). All of the flasks were incubated in the dark to prevent the possibility of photo-oxidation. $1 \mathrm{~mL}$ aliquots were transferred into $1.5 \mathrm{~mL}$ sterile microcentrifuge tubes at certain intervals and samples were centrifuged at $10000 \mathrm{rpm}$ for 3 minutes. The supernatant $(500 \mu \mathrm{L})$ was transferred to HPLC vial for TA analysis. HPLC analyses were carried out according to Wang and coauthors with slight modifications; the mobile phase was (80:20 methanol:water) at a flow rate of $0.4 \mathrm{~mL} / \mathrm{min}$. $1 \mu \mathrm{L}$ sample was injected to the Agilent Zorbax Eclipse PAH Column at $25{ }^{\circ} \mathrm{C}$ column temperature and the detection wavelength was 240 $\mathrm{nm}$. The analysis was carried out at ambient temperature. TA retention time was at 2.5 to 3 min [25].

\section{Operating CSTR for TA degradation}

We used artificial wastewater in terms of representing actual conditions in a continuous stirred tank reactor (CSTR). To test the microbial isolates with the best hydrocarbon degradation activities in a laboratoryscale reactor, an activated sludge sample was taken from pools in the aerobic biological treatment of the wastewater plant of the petrochemical industry.

The CSTR which used in operation was manufactured as previously explained [33]. Biological activated sludge was taken from the wastewater treatment unit from the petrochemical industry during a certain period was used as the initial sludge aging. From the moment sludge maturation takes place, it was seen that some parameters stable: $\mathrm{pH}$ was between 7.0-7.5; chemical oxygen demand (COD) was $1600 \mathrm{mgL}^{-1}$ dissolved oxygen (DO) was $4 \mathrm{mgL}^{-1}$; Mixed liquor suspended solids (MLSS) was $2500 \mathrm{mgL}^{-1}$.

CSTR has fed with artificial wastewater formulated as Glucose $1.5 \mathrm{~g}$, Peptone $0.6 \mathrm{~g}$, Urea $0.1 \mathrm{~g}$, $\mathrm{Na}_{2} \mathrm{HPO}_{4} .12 \mathrm{H}_{2} \mathrm{O} 0.0836 \mathrm{~g}, \mathrm{KH}_{2} \mathrm{PO}_{4} 0.0136 \mathrm{~g}, \mathrm{NaCl} 0.03 \mathrm{~g}, \mathrm{KCl} 0.014 \mathrm{~g}, \mathrm{CaCl}_{2} .2 \mathrm{H}_{2} \mathrm{O} 0.01854 \mathrm{~g}, \mathrm{MgSO}_{4} .7 \mathrm{H}_{2} \mathrm{O}$ $0.00262 \mathrm{~g}, \mathrm{FeCl}_{3} .6 \mathrm{H}_{2} \mathrm{O} 0.0166 \mathrm{~g}$ per liter. Once the appropriate MLSS values were reached in the tank, the isolates were inoculated into flasks contained with $50 \mathrm{~mL}$ of Nutrient Broth were incubated at $30^{\circ} \mathrm{C}$ in a rotary shaker for 48 hours Bacterial suspension (T1,T4,T5,TK) of concentration $10^{8} \mathrm{cfu} \mathrm{mL}^{-1}$ was prepared and 500 $\mathrm{mL}$ of the prepared bacterial suspension (10\% of the working volume) were added into the CSTR . The TA which previously prepared as the stock solution in DMSO was added to the tank at a final concentration of $50 \mathrm{mgL}^{-1}$ and TA biodegradation rates were measured by HPLC in every 24 or 48 hours. The degradation process was continued for 11 days. All the operations described above were repeated for the control tank. However, microbial isolates were not added to the control tank. 


\section{Microbial Monitoring During Degradation}

The microorganisms added to the tank were monitored by real-time PCR (LightCycler ${ }^{\circledR}$ 1.5, Roche Diagnostics, Germany) during TA biodegradation. For this, activated sludge samples were taken from the tank and total microbial DNA isolations were performed with the aforementioned DNA isolation kit in accordance with the manufacturer's instruction. Real-time PCR was performed using a TaqMan Probe system. LightCycler® TaqMan® Master Kit (Roche Diagnostics, Germany) was used in accordance with the manufacturer's instruction. PCR conditions were performed as an initial denaturation step at $95^{\circ} \mathrm{C}$ for 10 min for 1 cycle, amplification steps follow as denaturation at $95^{\circ} \mathrm{C}$ for $10 \mathrm{~s}$ for $1 \mathrm{cycle}$, annealing $46{ }^{\circ} \mathrm{C}$ for $30 \mathrm{~s}$, extension at $72{ }^{\circ} \mathrm{C}$ for $1 \mathrm{~s}$, for 45 cycles and cooling step at $40{ }^{\circ} \mathrm{C}$ for $30 \mathrm{~s}$, for 1 cycle, respectively for Burkholderia sp., initial denaturation at $95^{\circ} \mathrm{C}$ for $10 \mathrm{~min}$ for 1 cycle, amplification steps follow as denaturation at $95{ }^{\circ} \mathrm{C}$ for $10 \mathrm{~s}$ for $1 \mathrm{cycle}$, annealing at $55^{\circ} \mathrm{C}$ for $30 \mathrm{~s}$, extension at $72{ }^{\circ} \mathrm{C}$ for $1 \mathrm{~s}$, for 45 cycles and cooling step at $40{ }^{\circ} \mathrm{C}$ for $30 \mathrm{~s}$, for 1 cycle, respectively for Chryseobacterium sp. Primer-probe sets were designed for enumeration of the bacterial isolate in real-time PCR [34].

\section{RESULTS}

\section{HPLC results of microorganisms}

The HPLC analysis of the BH medium with TA showed a peak at $240 \mathrm{~nm}$ at 2.6 retention time. For the initial concentration of $100 \mathrm{mgL}^{-1}$, TA degradation was determined to be $100 \%$ for T1, T4, T5 and TK isolates at 8, 67, 52 and 24 hours, as shown in Figure 1. Although the most common bacteria in environment was T4, after 60 hours, there was still TA. Because we think that the genes that degradation of TA were expressed less than other bacteria. Sterile control flask, it was not observed biodegradation of TA.

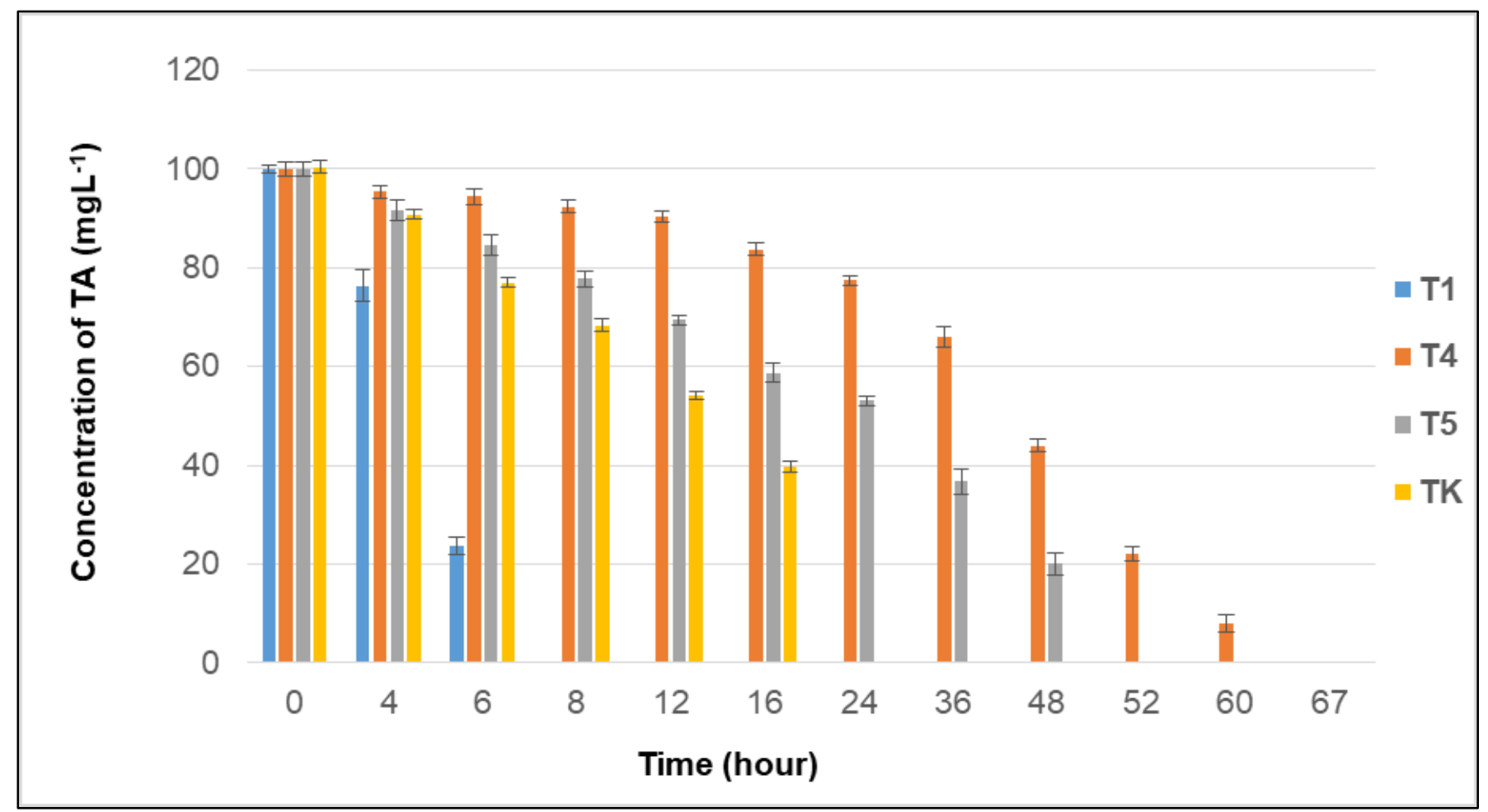

Figure 1. Biodegradation of TA by the isolated strains.

\section{Isolation and identification of TA degrading microorganisms}

TA degrading microorganisms were isolated from active sludge samples. 6 strains grew on TA containing $\mathrm{BH}$ medium. Among them, 4 strains were found to degrade TA. The biochemical and physiological characteristics of four strains are shown in Table 1. According to the results, Catalase and oxidase tests of all isolates were positively determined. T1, T4, T5 isolates were detected Gram-negative bacteria and TK was Gram-positive bacteria. However, the appearance of these isolates in the petri dish was determined to be different. 
Table 1. Characteristics of four bacteria.

\begin{tabular}{|c|c|c|c|c|}
\hline Identifying characteristic & T1 & T4 & T5 & TK \\
\hline Gram Stain & Gr - & Gr - & Gr - & $\mathrm{Gr}+$ \\
\hline KOH Test & + & + & + & - \\
\hline Catalase & + & + & + & + \\
\hline Oxidase & + & + & + & + \\
\hline Colonial color & light grey & orange & yellow & white \\
\hline
\end{tabular}

Subsequent 16S rRNA based phylogenetic analysis has demonstrated that the strains belonged to the genus as Arthrobacter sp., Chryseobacterium sp. Burkholderia sp. and Pseudomonas sp. The nucleotide sequences of $16 \mathrm{~S}$ rRNA of four strains determined in this study have deposited in the GenBank database (NCBI) and the accession numbers have presented in Table 2.

Table 2. Affiliations of bacterial $16 \mathrm{~S}$ rRNA gene sequences of $\mathrm{T} 1, \mathrm{~T} 4, \mathrm{~T} 5$ and $\mathrm{TK}$.

\begin{tabular}{cccc}
\hline Code of bacteria & Accession Number & Closest Species in GenBank & Similarity (\%) \\
\hline T1 & JX480627 & Pseudomonas sp. & 100 \\
T4 & JX480628 & Chryseobacterium sp. & 99 \\
T5 & JX480629 & Burkholderia sp. & 100 \\
TK & JX480630 & Arthrobacter sp. & 100 \\
\hline
\end{tabular}

Evolutionary analyses were conducted in MEGA7 [35]. On the basis of the consensus sequences for the 16S rRNA gene, and a phylogenetic tree was constructed using sequences from the 4 strain isolates (Figure 2) The phylogenetic tree analysis showed that the 4 bacteria shared high 16S rDNA gene sequence similarities. Members of the genera Chryseobacterium, Burkholderia, Pseudomonas, Arthrobacter were supported by $>99 \%$ bootstrap value and were well-established. 


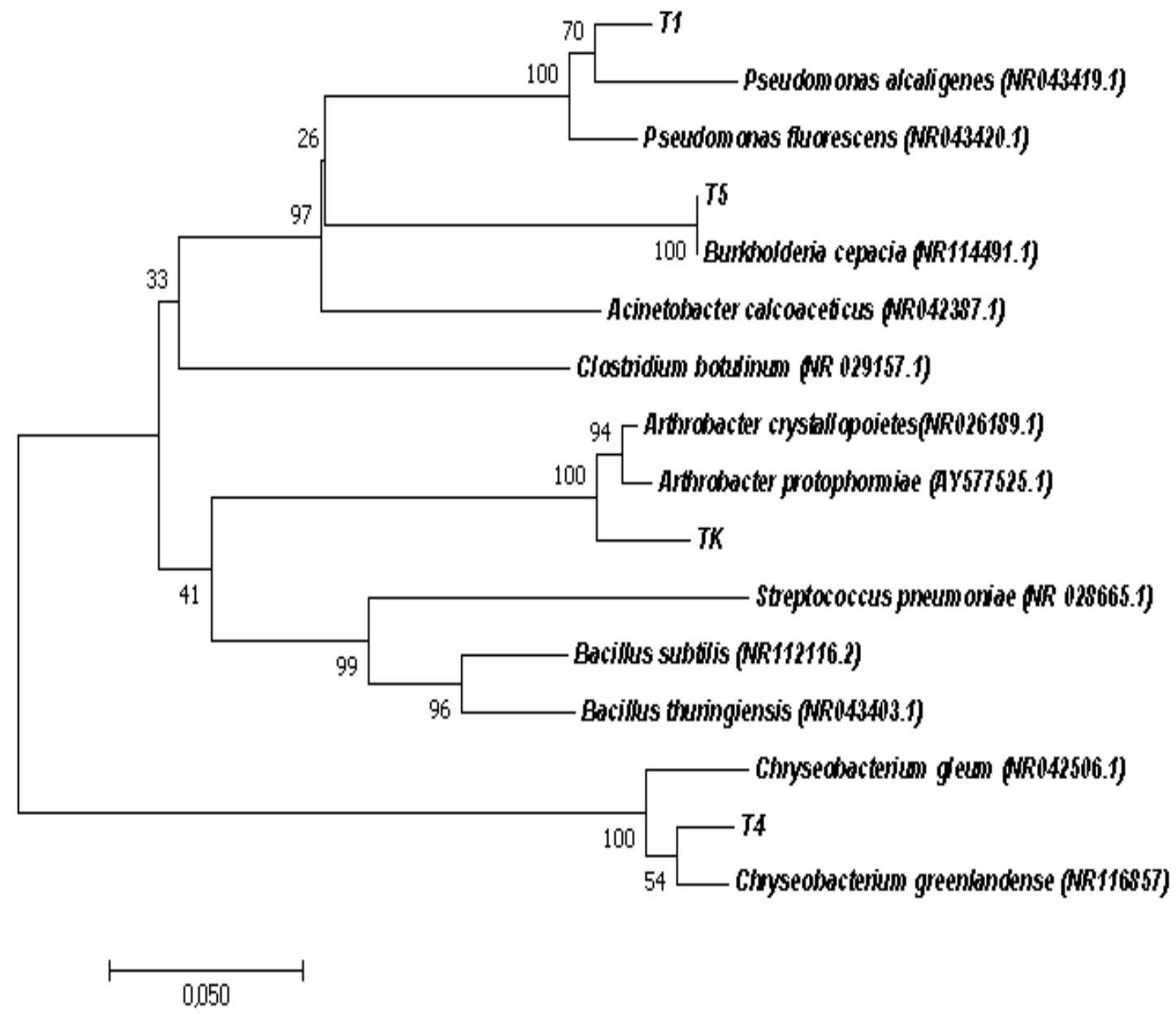

Figure 2. Dendrograms of sequence alignments of the 16S rRNA gene. T1:Pseudomonas sp. (JX480627), T4: Chryseobacterium sp. (JX480628), T5: Burkholderia sp.(JX480629), TK: Arthrobacter sp.(JX480630). The scale bar indicates 0.05 estimated changes per nucleotides and the numbers showed the bootstrap values representing percentage confidence of 1000 replicate analysis.

Microbial monitoring was performed in the inoculated CSTR during 11 days period. Two isolates were monitored with real-time PCR. As seen in Figure 3, while Chryseobacterium sp. is the most abundant bacterium in the first 6 days in inoculated CSTR. The number of Burkholderia sp. has increased gradually during the degradation process. Although numbers of two bacteria are almost equal on the 7th day, numbers have decreased relatively from the 9th day. The first number of copy DNA of Chryseobacterium sp. was calculated as $4.0 \times 10^{6}$; at the end of 11 days, Chryseobacterium sp. was calculated as $5.4 \times 10^{5}$. Approximately $1 \mathrm{log}$ of decrease has taken place in the number of Chryseobacterium sp., Burkholderia sp. was calculated as $8.1 \times 10^{4}$ at the beginning and $2.4 \times 10^{4}$ at the end of 11 days. It could be said that the number of Burkholderia $\mathrm{sp}$. was not significantly changed when compared with the beginning. 


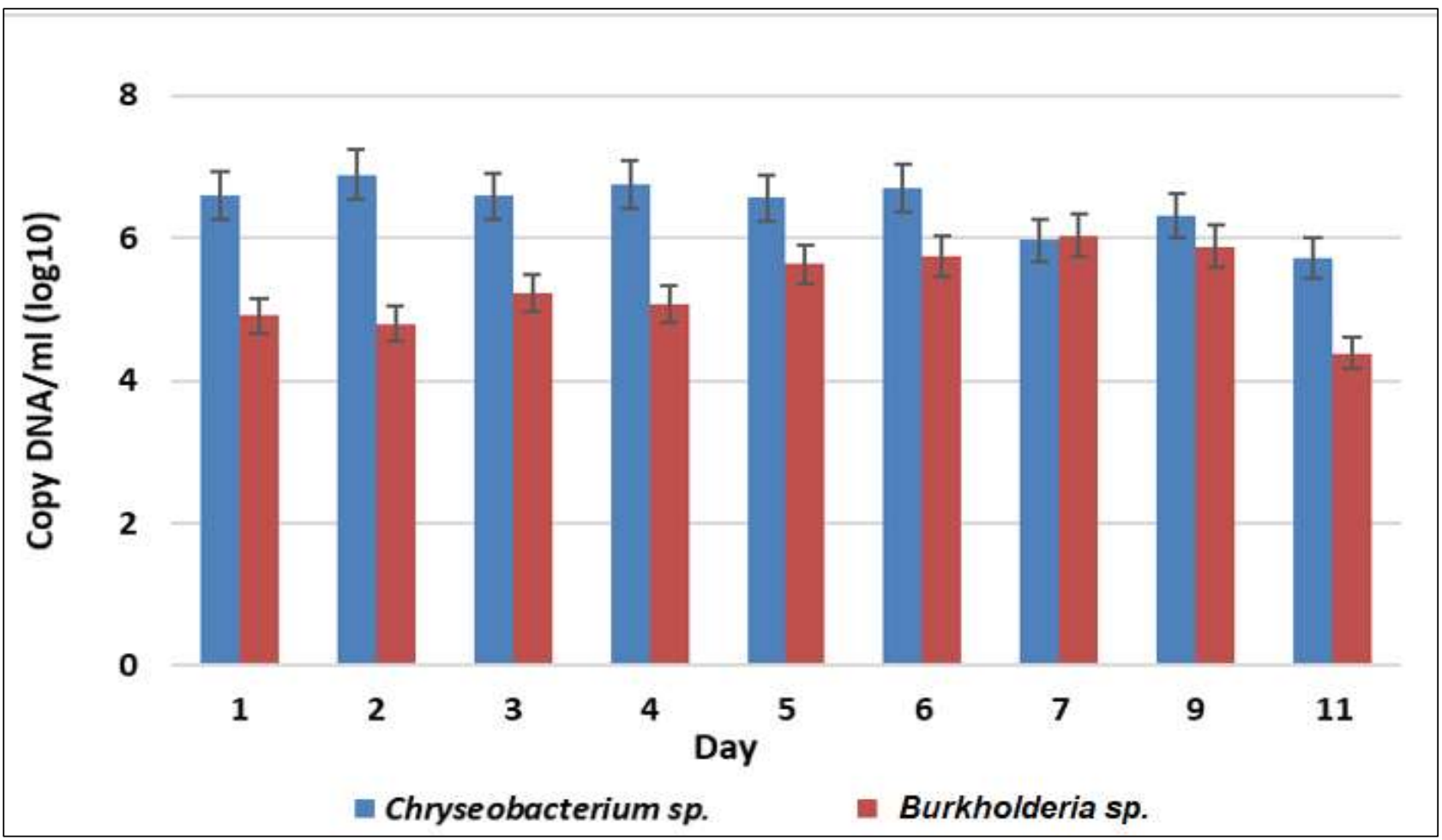

Figure 3. Copy DNA numbers of two selected bacteria during the biodegradation process. Each bar indicates that individual copy numbers of bacterial DNA at the $\log 10$ base (error bars calculated as a percentage).

The initial concentration of TA is $50 \mathrm{mgL}^{-1}$ in inoculated and non-inoculated CSTR. $50 \mathrm{mgL}^{-1} 56.4 \%$ of TA degraded in the inoculated CSTR in first 24 hours by activated sludge which inoculated with degradative microorganisms, while $32 \%$ of $50 \mathrm{mg} \mathrm{L}^{-1}$ of TA degraded in the non-inoculated CSTR. $85.8 \%$ of TA degraded in inoculated CSTR after 11 days, but $42.1 \%$ of TA degraded in non-inoculated CSTR after 11 days. The efficiency of inoculated CSTR approximately $50 \%$ more effective than non-inoculated CSTR, and in the light of these data, it is clear that inoculated CSTR has better performance (Figure 4).

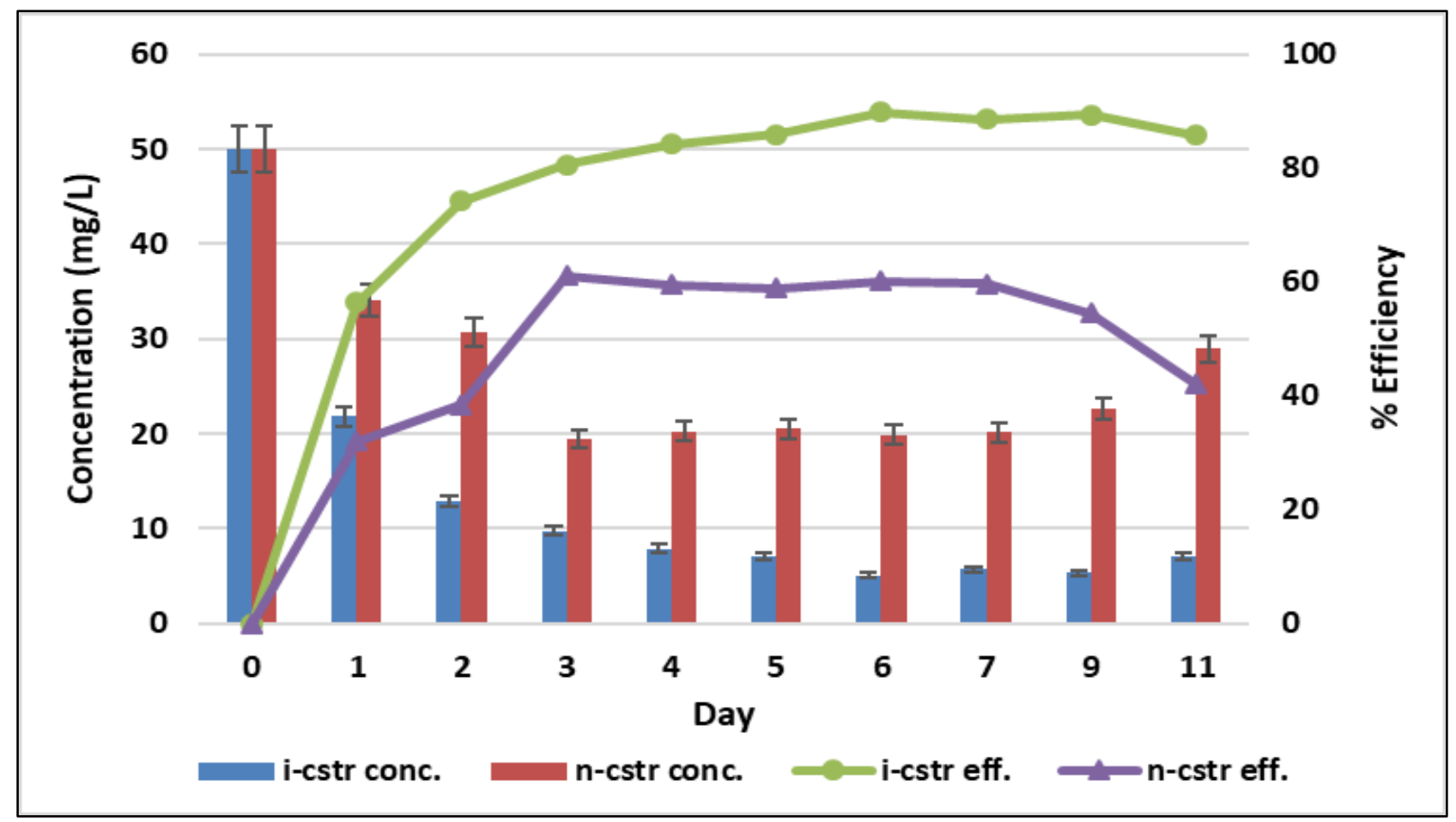

Figure 4. The graph shows the concentrations of TA determined in the effluent during the degradation and the removal efficiencies. (i-cstr: inoculated CSTR with degradative isolates, n-cstr: non-inoculated CSTR as control). 


\section{DISCUSSION}

Biodegradation, one of the popular topics, basically involves the conversion of complex polluants to simpler ones by using microorganisms. This biological method proves to be less expensive than other methods used for cleaning up hazardous waste. Numerous studies have been reported that on the biodegradation of wastewater treatment. Biodegradation of chemicals such as phthalates, polyaromatic hydrocarbons (PAH), benzene, toluene, phenol was studied by many researchers $[24,36,37,38,39]$. In this study, the removal of TA via bacteria and bioaugmented sludge is effective. We understand that, different bacteria can degrade TA in different times.

Four isolates from petrochemical wastewater were obtained in $\mathrm{BH}$ medium containing TA $\left(100 \mathrm{mgL}^{-1}\right)$ as the sole carbon source. T1 isolate showed the ability to degrade $100 \mathrm{mgL}^{-1} \mathrm{TA}$ in 8 hours. Morphological characteristics of the 3 isolates were found to be a Gram-negative and 1 isolate was Gram-positive on the screening medium. These bacteria were identified as Arthrobacter sp., Chryseobacterium sp. Burkholderia $\mathrm{sp}$. and Pseudomonas sp. (T1) have the best result for biodegradation of TA. This study petrochemical wastewaters in Turkey, to obtain 4 different bacteria differ in terms of degrading TA. Also, Chryseobacterium $\mathrm{sp}$. has not been reported to be isolated in TA biodegradation studies so far. T1 isolate (degrade of TA in 8 hours) revealed its difference from other studies.

To date, many phthalates degrading bacterial strains such as; Flavobacterium sp., Pseudomonas aeruginosa PP4, Comamonas acidovorans Fy-1, Burkholderia cepacia DB01 were isolated and characterized in a few studies [23,40,41,42]. Pseudomonas and Burkholderia, which were used in our study, were used in many previous studies for phthalate degradation. Numerous studies have shown that TA is intrinsically biodegradable under aerobic conditions. To remove TA from wastewater, the biodegradation method is very efficient and rapid. Rhodococcus and Pseudomonas play a fundamental role in biodegradation $[43,44]$. Biodegradation of phthalates may be carried out syntrophically by the microbial consortium [45]. The other study reported that degradation of phthalate was accelerated by consortia which are Corynebacterium sp. 018 and Sphingomonas sp. DK4 [46].

Pseudomonas sp. and Arthrobacter sp. were not detected in real-time PCR, because of selected primers did not work in real-time PCR, but they were determined by conventional PCR. We have commented that primer specificities of these bacteria are less adequate in fluorescent technology than in conventional ones. We observed that isolate T1 had degraded TA in 8 hours in the flask assays before CSTR. However, the elapsed time in the degradation process is thought to extend due to different parameters such as physicochemical interactions and reaching of TA to targeted microorganisms within the activated flocs in CSTR. The fluctuation of the TA in non-inoculated CSTR directly depends on the microbial situations in the population. This situation is a significant sign of microbial dynamics in the population. Also, it could be considered as a difference in microbial lifespans. Although some bacterial groups utilize TA as carbon and energy source more quickly and reach the plateau phase in the logarithmic curve, other ones can behave in the opposite ways such as low doubling in time and need more time reaching the plateau phase.

Further research on biodegradation pathways, microorganisms' responsibility and limiting factors for degradation of hazardous chemicals are necessary before applying microbes in the field, which helps to achieve success in biodegradation of dangerous chemicals. Results from this study suggest that inoculation and acclimation of degradative microorganisms into activated sludge positively affect the degradation process via increasing the degradation capacity and more concentration. Acclimation and bioaugmentation processes could be the critical factors for the degradation of some xenobiotics and chemicals, which will be more effective in this way.

Funding: This work was funded by the research project SANTEZ-00639 STZ 2010-2 of the Republic of Turkey, Ministry of Science, Industry of Technology and Ege University, Scientific Research Project (10-FEN-060).

Acknowledgments: This work was funded by the research project SANTEZ-00639 STZ 2010-2 of the Republic of Turkey, Ministry of Science, Industry of Technology and Ege University, Scientific Research Project (10-FEN-060).

Conflicts of Interest: The authors declare no conflict of interest. The funders had no role in the design of the study; in the collection, analyses, or interpretation of data; in the writing of the manuscript, or in the decision to publish the results. 


\section{REFERENCES}

1. Liang DW, Zhang T, Fang HH, He J. Phthalates biodegradation in the environment. Appl. Microbiol. Biotechnol. 2008;80:183-98.

2. Hashizume K, Nanya J, Toda C, Yasui T, Nagano H, Kojima N. Phthalate esters detected in various water samples and biodegradation of the phthalates by microbes isolated from river water. Biol. Pharm. Bull. 2002;25:209-14.

3. Ribbons DW, Keyser P, Kunz DA, Taylor BF, Gibson DT. Microbial degradation of phthalates, Microbial degradation of organic compounds, Marcel Dekker, New York. 1984;371-97.

4. Sheehan RJ. Terephthalic Acid, Dimethyl Terephthalate, and Isophthalic Acid" in Ullmann's Encyclopedia of Industrial Chemistry, Wiley-VCH, Weinheim;2002.

5. USA-EPA. Code of Federal Regulations Part 136;1992.

6. Zhang XX, Wan YQ, Cheng SP, Sun SL, Zhu CJ, Li WX, Zhang XC, Wang GL, Lu JH, Luo X, Gu JD. Purified terephthalic acid wastewater biodegradation and toxicity. J. Environ. Sci. 2005;17: 876-80.

7. Jobling S, Reynolds T, White R, Parker, MG, Sumpter JP. A variety of environmentally persistent chemicals, including some phthalate plasticizers, are weakly estrogenic. Environ. Health Perspect. 1995;103:582-7.

8. Wolf C, Lambright C, Mann P, Price M, Copper RL, Ostby J, Gray LE. Administration of potentially antiandrogenic pesticides (procymidone, linuron, iprodione, chlozolinate, p,p'-DDE, and ketoconazole) and toxic substances (dibutyl- and diethylhexyl phthalate, PCB 169, and ethane dimethane sulphonate) during sexual differentiation produces diverse profiles of reproductive malformations in the male rat. Toxicol. Ind. Health.1999;15:1(2)94-118.

9. Matsumoto M, Hirata-Koizumi M, Ema M. Potential adverse effects of phthalic acid esters on human health: a review of recent studies on reproduction. Regul. Toxico.I Pharm. 2008;50:37-49.

10. Karegoudar TB, Pujar BG. Degradation of terephthalic acid by a Bacillus species. FEMS Microbiol Lett.1985;30:217-20.

11. Chang BV, Yang $\mathrm{CM}$, Cheng $\mathrm{CH}$, Yuan SY. Biodegradation of phthalate esters by two bacteria strains. Chemosphere. 2004;55:533-8.

12. Zeng F, Cui K, Li X, Fu J, Sheng G. Biodegradation kinetics of phthalate esters by Pseudomonas fluoresences FS1. Process Biochem. 2004;39:1125-9.

13. Miranda RC, Souza CS, Gomes EB, Lovaglio RB, Lopes CE, Souza MFVQ. Biodegradation of diesel oil by yeast from the vicinity of Suape Port in the State of Pernambuco - Brazil. Braz. Arch. Biol. Technol. 2007;50(1):147-52.

14. Morais EB, Tauk-Tornisielo SM. Biodegradation of oil refinery residues using mixed culture of microorganisms isolated from a landfarming. Braz. Arch. Biol. Technol. 2009;52(6):1571-8.

15. Wen ZD, Wu WM, Ren NQ, Gao DW. Synergistic effect using vermiculite as media with a bacterial biofilm of Arthrobacter sp. for biodegradation of di-(2-ethylhexyl) phthalate. J. Hazard. Mater. 2015;304:118-25.

16. Das N, Chandran P. Microbial Degradation of Petroleum Hydrocarbon Contaminants: An Overview. Biotechnol. Res. Int.2011.

17. Neilson AH, Allard AS. Environmental Degradation and Transformation of Organic Chemicals 2, CRC Press.2008.

18. Ward O, Singh A, Van-Hamme J. Accelerated biodegradation of petroleum hydrocarbon waste, J. Ind. Microbiol. Biotechnol. 2003;30:260-70.

19. Shokrollahzadeh S, Azizmohseni F, Golmohammad F, Shokouhi H, Khademhaghighat F. Biodegradation potential and bacterial diversity of a petrochemical wastewater treatment plant in Iran. Bioresour.Technol. 2008;6127-33.

20. Gerardi MH. Wastewater bacteria, Wiley-Interscience.2006.

21. Kleerebezem R, Mortier J, Pol LWH, Lettinga G. Anaerobic pre-treatment of petrochemical effluents: Terephthalic acid wastewater. Water Sci Technol 1997;36:237-48.

22. Qiu YL, Sekiguchi Y, Hanada S, Imachi Tseng IC, Cheng SS, Ohashi A, Harada H, Kamagata Y. Pelotomaculum terephthalicum sp nov. and Pelotomaculum isophthalicum sp nov.: two anaerobic bacteria that degrade phthalate isomers in syntrophic association with hydrogenotrophic methanogens. Arch. Microbiol. 2006;185:172-82.

23. Vamsee-Krishna C, Mohan Y, Phale PS. Biodegradation of phthalate isomers by Pseudomonas aeruginosa PP4, Pseudomonas sp PPD and Acinetobacter Iwoffii ISP4. Appl Microbiol Biotechnol. 2006;72:1263-9.

24. Zhang YM, Sun YQ, Wang ZJ, Zhang J. Degradation of terephthalic acid by a newly isolated strain of Arthrobacter sp.0574. S. Afr. J. Sci.2013;109:7-8.

25. Wang JZ, Teng L, Zhang J, Huang X, Zhang JF. Study on optimal biodegradation of terephthalic acid by an isolated Pseudomonas sp. Afr. J. Biotechnol. 2011;10(16): 3143-8.

26. Zhang W, Zhang J, Zheng L, Gong J. The Isolation, Identification, and Fermentation of Bacillus for Degradation of Terephthalic Acid.Trans Tech Publications, 2011;1662-8985,183-185:942-6.

27. Suwanawat N, Parakulsuksatid P, Nitayapat N, Sanpamongkolchai W. Biodegradation of Terephthalic Acid by Rhodococcus biphenylivorans Isolated from Soil. Int. J. Environ. Sci. Dev.2019;10(1):30-3. 
28. Akarsubasi AT, Ince O, Kirdar B, Oz NA, Orhon D, Curtis TP, Head IM, Ince BK. Effect of wastewater composition on archaeal population diversity. Water Res. 2005;39(8):1576-84.

29. Heid CA, Stevens J, Livak KJ, Williams PM. Real-time quantitative PCR. Genome Res.1996;6:986-94.

30. Yu Y, Lee C, Kim J, Hwang S. Group-specific primer and probe sets to detect methanogenic communities using quantitative real-time polymerase chain reaction. Biotechnol. Bioeng. 2005;89(6):670-9.

31. Bushnell LD, Haas HF. The Utilization Of Certain Hydrocarbons By Microorganisms, J Bacteriol. 1941;41(5):65373.

32. Miller CS, Handley KM, Wrighton KC, Frischkorn KR, Thomas BC, Banfield JF. Short-read assembly of full-length $16 \mathrm{~S}$ amplicons reveals bacterial diversity in subsurface sediments. PloS One.2013;8(2):56018

33. Sponza DT, Gök O. Aerobic biodegradation and inhibition kinetics of polyaromatic hydrocarbons (PAHs) in a petrochemical industry wastewater in the presence of biosurfactants, J. Chem. Technol. Biotechnol. 2012;87:65872.

34. Vural C, Karabey B, Bayrak DE, Ozdemir G. Real-time Bacterial Monitoring during the Biodegradation of Selected PAHs in Industry-borne Activated Sludge. J Environ Prot Ecol. 2014;15 (3):1028-33.

35. Kumar S, Stecher G, Tamura K. MEGA7: molecular evolutionary genetics analysis version 7.0 for bigger datasets. Mol. Biol. Evol.2016;33:1870-4.

36. Jin D, Kong X, Li Y, Bai Z, Zhuang G, Zhuang X, Deng Y. Biodegradation of di-n-Butyl Phthalate by Achromobacter sp. Isolated from Rural Domestic Wastewater. Int. J. Environ. Res. Public Health. 2015;12(10):13510-22.

37. Ling J, Zhang G, Sun H, Fan Y, Ju J, Zhang C. Isolation and characterization of a novel pyrene-degrading Bacillus vallismortis strain JY3A. Sci Total Environ. 2011;409:1994-2000.

38. Wolicka D, Suszek A, Borkowski A, Bielecka A. Application of aerobic microorganisms in bioremediation in situ of soil contaminated by petroleum products. Biores. Technol. 2009;100:3221-7.

39. Geng A, Soh A, Lim C, Loke L. Isolation and characterization of a phenol-degrading bacterium from industrial activated sludge. Appl Microbiol Biotechnol. 2006;71:728-35.

40. Tanaka T, Yamada K, lijima T, Iriguchi T, Kido Y. Complete degradation of the endocrine-disrupting chemical phthalic acid by Flavobacterium sp. J. Health Sci. 2006; 52:800-4.

41. Wang YY, Fan YZ, Gu JD. Aerobic degradation of phthalic acid by Comamonas acidovorans Fy-1 and dimethyl phthalate ester by two reconstituted consortia from sewage sludge at high concentrations. World $\mathrm{J}$ Microbiol Biotechnol. 2003;19:811-5.

42. Chang HK, Zylstra GJ. Novel organization of the genes for phthalate degradation from Burkholderia cepacia DBO1. J Bacteriol. 1998;180:6529-37.

43. Brooijmans RJW, Pastink MI, Siezen RJ. Hydrocarbon-degrading bacteria: the oil-spill clean-up crew. Microb. Biotechnol. 2009;2:587-94.

44. Zhao F, Zhou JD, Ma F, Shi RJ, Han SQ, Zhang J, Zhang Y. Simultaneous inhibition of sulfate-reducing bacteria, removal of $\mathrm{H}_{2} \mathrm{~S}$ and production of rhamnolipid by recombinant Pseudomonas stutzeri Rhl: applications for microbial enhanced oil recovery. Bioresour.. Technol.2016;207:24-30.

45. Gu JD, Li J, Wang Y. Biochemical pathway and degradation of phthalate ester isomers by bacteria. Water Sci. Technol. 2005;52:241-8.

46. Chang BV, Yang $\mathrm{CM}$, Cheng $\mathrm{CH}$, Yuan SY. Biodegradation of phthalate esters by two bacteria strains. Chemosphere. 2004;55:533-8.

(c) 2021 by the authors. Submitted for possible open access publication under the terms and conditions of the Creative Commons Attribution (CC BY NC) license (https://creativecommons.org/licenses/by-nc/4.0/). 